\title{
Hybrid organo-inorganic composite materials of incorporative type based on calcium phosphates for bone surgery
}

\author{
S.P.Krivileva ${ }^{1}$, O.M.Rassokha ${ }^{1}$, O.Yu.Zakovorotnyi ${ }^{1}$, \\ M.G.Zinchenko ${ }^{1}$, N.O.Bukatenko ${ }^{1}$, V.I.Zhukov \\ ${ }^{1}$ National Technical University "Kharkiv Polytechnic Institute", \\ 2 Kyrpichova Str., 61000 Kharkiv, Ukraine \\ ${ }^{2}$ Kharkiv National Medical University, 4 Nauky Ave., \\ 61000 Kharkiv, Ukraine
}

Received January 18, 2018

\begin{abstract}
Proposed is a concept for the obtaining of a hybrid organo-inorganic composite material of incorporative type with a binder based on sevilen and an inorganic filler based on nanoparticles of $\mathrm{Ca}_{3}\left(\mathrm{PO}_{4}\right)_{2}$ nanoparticles. The binder simultaneously contains two different phases: $\alpha$ - and $\beta$-modifications of $\mathrm{Ca}_{3}\left(\mathrm{PO}_{4}\right)_{2}$ separated by a coherent boundary. It is shown that during the formation of the composite several processes occur simultaneously. They are: partial hydration of $\alpha-\mathrm{Ca}_{3}\left(\mathrm{PO}_{4}\right)_{2}$, partial hydrolysis of sevilen, as well as intermolecular structuring due to the formation of chelate complexes. Studied is the effect of the composition, structure, the ratio of initial components on the properties of the composite.

Keywords: hybrid organo-inorganic composite, coherent boundary, incorporative type, structuring mechanism, chelate complex.

Разработана концепция получения гибридного органо-неорганического композиционного материала инкорпоративного типа со связующим на основе сополимера этилена с винилацетатом и неорганическим наполнителем на основе наночастиц $\mathrm{Ca}_{3}\left(\mathrm{PO}_{4}\right)_{2}$, в структуре которых одновременно присутствуют две разные фазы: $\alpha$ и $\beta$-модификации $\mathrm{Ca}_{3}\left(\mathrm{PO}_{4}\right)_{2}$ с когерентной границей между ними. Определено, что при формировании композита одновременно протекают частичные гидратация $\alpha-\mathrm{Ca}_{3}\left(\mathrm{PO}_{4}\right)_{2}$, гидролиз СЭВА и межмолекулярное структурирование за счет образования хелатных комплексов. Изучено влияние состава, структуры и соотношения компонентов на свойства композита.
\end{abstract}

Гібридні органо-неорганічні композиційні матеріали інкорпоративного типу на основі фосфатів кальцію для кісткової хірургії. С.П.Кривільова, О.М.Рассоха, О.Ю.Заковоротний, М.Г.Зінченко, Н.О.Букатенко, В.І.Жуков.

Розроблено концепцію отримання гібридного органо-неорганічного композиційного матеріалу інкорпоративного типу із сполучним на основі сополімера етилену з винилацетатом i неорганічним наповнювачем на основі наночасток $\mathrm{Ca}_{3}\left(\mathrm{PO}_{4}\right)_{2}$, в структурі яких одночасно присутні відразу дві різні фази: $\alpha$ і $\beta$-модифікації $\mathrm{Ca}_{3}\left(\mathrm{PO}_{4}\right)_{2}$ з когерентною межею між ними. Визначено процеси, що протікають при формуванні композиту: часткова гідратація $\alpha-\mathrm{Ca}_{3}\left(\mathrm{PO}_{4}\right)_{2}$, частковий гідроліз CEBA і міжмолекулярне структурування за рахунок утворення хелатних комплексів. Вивчено вплив складу, структури і співвідношення вихідних компонентів на властивості композита. 


\section{Introduction}

Creation of new-generation functional materials for medicine and biology is a topical problem. Present-day biological materials science offers a variety of materials, including nanodimensional ones [1-5] for surgery of osteoarticular system.

However, so far numerous comprehensive investigations have not resulted in the obtaining of innovative materials meant for fixation of bone fragments and filling of large cavities in major skeleton bones.

Correction of structural disorders in different skeleton parts requires the use of special materials. In particular, filling of cavities in major bones is realized by means of calcium phosphate cements [6,7].

For improvement of the properties of bone cements (e.g. their mechanical strength) there are applied different additives, such as chitosan, organic and inorganic fibers, metals or powders of apatite composition [8-16]. The latter group includes fluorine apatite $\mathrm{Ca}_{10}\left(\mathrm{PO}_{4}\right)_{6} \mathrm{~F}_{2}$, fluorine carbonate apatite $\mathrm{Ca}_{10} \mathrm{~F}_{2}\left(\mathrm{PO}_{4}, \mathrm{CO}_{3}\right)_{6}$, chlorapatite $\mathrm{Ca}_{10}\left(\mathrm{PO}_{4}\right)_{6} \mathrm{Cl}_{2}$ and hydroxyl apatite $\mathrm{Ca}_{10}\left(\mathrm{PO}_{4}\right)_{6}(\mathrm{OH})_{2}$ [17]. As concerns the compliance of the chemical composition of an inorganic filler with the one of bone tissue, the most effective is nanocrystalline $\mathrm{Ca}_{10}\left(\mathrm{PO}_{4}\right)_{6}(\mathrm{OH})_{2}$ possessing high biocompatibility that provides good binding between the material and living bones. Introduction of $\mathrm{Ca}_{10}\left(\mathrm{PO}_{4}\right)_{6}(\mathrm{OH})_{2}$ in quantities of 12.5-50 wt. \% into the composition of the filler raises its mechanical strength [16]. However, the working characteristics of well-known bone cements do not allow to use them for fixation of bone fragments and filling of cavities in bone tissue.

For these purposes, the use of hybrid organo-inorganic composite materials seems to be most promising. Organo-inorganic composites of incorporative type belong to a new class of nanomaterials formed by incorporation of inorganic fillers into organic matrices [18].

The use of calcium phosphate inorganic fillers based on $\mathrm{Ca}_{3}(\mathrm{PO})_{4}$ and $\mathrm{Ca}_{10}\left(\mathrm{PO}_{4}\right)_{6} \mathrm{~F}_{2}$ will make it possible to raise the strength of the material and its stability in chemically aggressive medium of living organisms. Thereat, the content of fluorine must not be high, since this may lead to unpredictable serious consequences (such as fluorosis). In the capacity of polymer binder for the hybrid polymer materials meant for plasty of defects in osteoarticular system, there was chosen ethylene-vinyl acetate copolymer (sevilen) in the form of stabilized aqueous dispersion. It possesses high adhesion to bone tissue, resistance to physical and chemical aggressive media and can be structured by means of smoothly proceeding reactions with participation of acetate groups. Stabilization of aqueous dispersion of sevilen is realized using a colloid, e.g. polyvinyl alcohol. As established in [19], a prolonged exposure of such a hybrid material in (physiologic) saline or the biological medium of the organism of warm-blooded animals may give rise to partial hydrolysis of sevilen followed by the formation of the ternary ethylene-vinyl acetate-vinyl alcohol copolymer. Due to hydrolysis of the acetate groups in sevilen, there are formed additional hydroxyl groups which interact with calcium hydroxyl apatite ions with subsequent formation of chelate compounds.

The aim of the present work was to create hybrid organo-inorganic composite materials of incorporative type based on calcium phosphates to be used in bone surgery.

To achieve this aim, it was necessary to solve the following problems:

- To develop a concept for the obtaining of a hybrid organo-inorganic composite material of incorporative type based on the use of $\mathrm{Ca}_{3}\left(\mathrm{PO}_{4}\right)_{2}$ nanoparticles with the structure simultaneously containing two different phases: $\alpha$ - and $\beta$-modifications of $\mathrm{Ca}_{3}\left(\mathrm{PO}_{4}\right)_{2}$ separated by a coherent boundary.

- To study the influence of the composition of the initial components and the conditions of their thermal treatment on the formation of fragmentary structure of the nanocrystalline inorganic filler and the complex of its physical, mechanical, technological and biological characteristics. To use the obtained data for the development of a simplified technological scheme for the synthesis of bioceramic materials to be applied in the capacity of fillers for organo-inorganic biocomposites of incorporative type.

- To investigate the processes of formation and in vivo performance of the polymer composite with the binder based on the copolymer of ethylene vinyl acetate and nanodisperse inorganic filler on the base of calcium phosphate, leading to stabilization of its strength properties. Such processes include partial hydration of $\alpha-\mathrm{Ca}_{3}\left(\mathrm{PO}_{4}\right)_{2}$, partial hydrolysis of sevilen with subsequent formation of the ternary ethylene-vinyl acetate-vinyl alcohol copolymer as well as intermolecular structuring due to the formation of chelate complexes. 
Table 1. Composition of the hybrid organo-inorganic composite material

\begin{tabular}{|c|c|c|c|c|c|}
\hline \multirow[t]{2}{*}{ Composite } & \multicolumn{5}{|c|}{ Component } \\
\hline & $\begin{array}{l}\text { Ethylene-vinyl acetate } \\
\text { copolymer with } 75000- \\
125000 \text { molecular mass } \\
\text { and } 28-32 \text { mass } \% \\
\text { content of vinyl acetate }\end{array}$ & $\begin{array}{c}\text { Polyvinyl alcohol } \\
\text { with } 5-14 \text { wt. } \% \\
\text { content of acetate } \\
\text { groups }\end{array}$ & $\begin{array}{l}\text { Inorganic } \\
\text { filler }\end{array}$ & Chlorophyllipte & Water \\
\hline 1 & 22.00 & 2.0 & 59.00 & 0.005 & The rest \\
\hline 2 & 26.00 & 3.0 & 55.00 & 0.006 & The rest \\
\hline 3 & 30.00 & 4.0 & 51.00 & 0.007 & The rest \\
\hline 4 & 20.00 & 1.5 & 62.00 & 0.004 & The rest \\
\hline 5 & 32.00 & 4.5 & 57.00 & 0.008 & The rest \\
\hline 6 & - & 3.0 & 55.00 & 0.006 & The rest \\
\hline 7 & - & 3.0 & 55.00 & 0.006 & The rest \\
\hline 8 & - & 3.0 & 55.00 & 0.006 & The rest \\
\hline 9 & - & 3.0 & 55.00 & 0.006 & The rest \\
\hline 10 & 26.00 & - & 55.00 & 0.006 & The rest \\
\hline 11 & 26.00 & - & 55.00 & 0.006 & The rest \\
\hline 12 & 26.00 & 3.0 & 55.00 & 0.006 & The rest \\
\hline 13 & 26,00 & 3.0 & - & 0.006 & The rest \\
\hline 14 & 26.00 & 3.0 & - & 0.006 & The rest \\
\hline 15 & 26.00 & 3.0 & - & 0.006 & The rest \\
\hline 16 & 26.00 & 3.0 & - & 0.006 & The rest \\
\hline 17 & - & - & 55.00 & 0.006 & The rest \\
\hline 18 & - & - & 55.00 & 0.006 & The rest \\
\hline
\end{tabular}

- To study the influence of the ratio of ingredients in the composite material, the structure of the filler, the properties of the binder and the temperature factor on the rate of the processes resulting in stabilization of the strength properties of the composite and the degree of their completeness.

- To study the influence of the ratio of organic and inorganic components in the organo-inorganic composite material, on the complex of its physico-mechanical and technological properties and behaviour in the living organism medium.

\section{Experimental}

In the present study there were used high-purity $\mathrm{Ca}(\mathrm{OH})_{2}, \mathrm{CaF}_{2}$ and $\mathrm{H}_{3} \mathrm{PO}_{4}$ as well as synthesized $\mathrm{Ca}_{3}\left(\mathrm{PO}_{4}\right)_{2}$ and $\mathrm{Ca}_{10}\left(\mathrm{PO}_{4}\right)_{6} \mathrm{~F}_{2}$ nanopowders. $\mathrm{Ca}_{3}\left(\mathrm{PO}_{4}\right)_{2}$ was obtained using $\mathrm{H}_{3} \mathrm{PO}_{4}$ and $\mathrm{Ca}(\mathrm{OH})_{2}$ in solid phase by thrice-repeated burning of the tableted mixtures with two-hour ageing at $1150-1250^{\circ} \mathrm{C}$ and intermediate grinding during multi-step rise of the temperature at a rate of $120-150^{\circ} \mathrm{C} / \mathrm{hr}$. Fluorine apatite
$\mathrm{Ca}_{10}\left(\mathrm{PO}_{4}\right)_{6} \mathrm{~F}_{2}$ was synthesized from $\mathrm{CaF}_{2}$ and $\mathrm{Ca}_{3}\left(\mathrm{PO}_{4}\right)_{2}$ preliminarily obtained in solid phase by burning at $1200-1250^{\circ} \mathrm{C}$ with three-hour ageing and subsequent grinding.

The samples were sintered using a hightemperature chamber furnace containing air with Si-C heaters, as well as an electric furnace with krypton resistance and quartz capsule at the bottom. The temperature was controlled by Pt-Rh thermocouples.

The phase composition of the materials was controlled by the method of X-ray phase analysis on a set up of Drone-3 type. The mineralogical composition of the inorganic filler and the morphology of the composite material particles were determined by means of a Carl Zeiss scanning electron microscope by the method of two-stage cellulose-carbon and extraction replicas. Different polymorphic modifications of $\mathrm{Ca}_{3}\left(\mathrm{PO}_{4}\right)_{2}$, namely, $\alpha$ - and $\beta$-modifications, separated by a coherent boundary were determined in the nanoparticle structure in situ microscopically, from distinctions in the interference color of the crystals taking into account the known optical constants of 

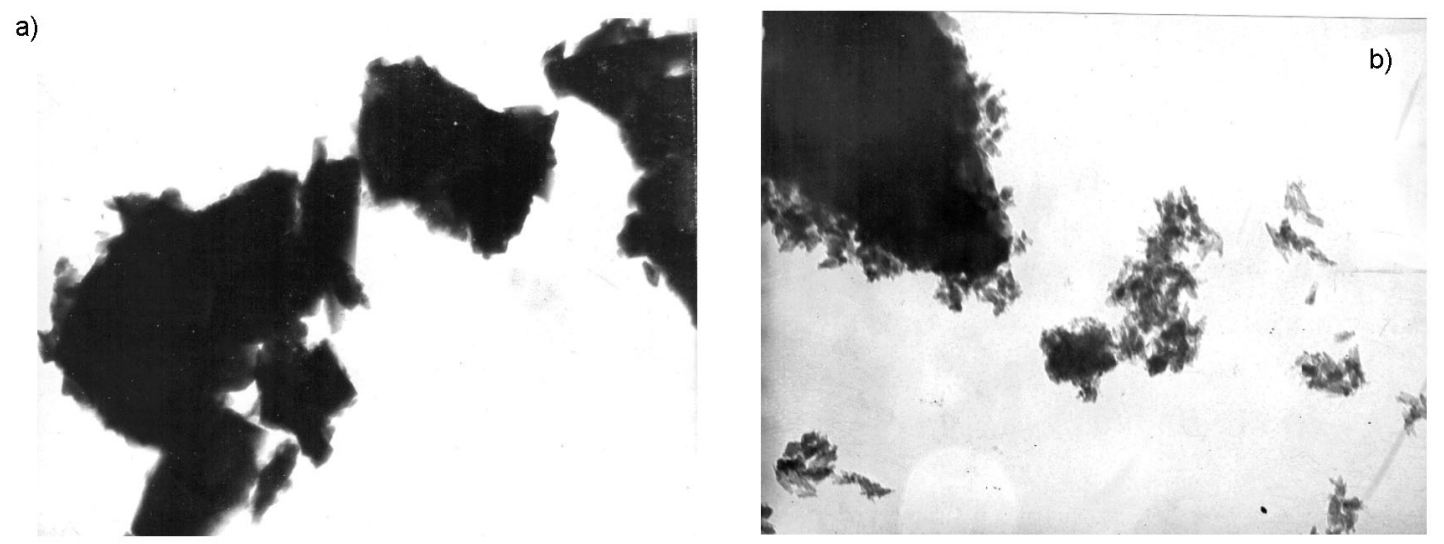

Fig. 1. SEM microstructure micrograms of : a) nanocrystalline powder based on $\mathrm{Ca}_{3}\left(\mathrm{PO}_{4}\right)_{2}, \times 50000$; b) nanocrystalline powder $\mathrm{Ca}_{3}\left(\mathrm{PO}_{4}\right)_{2} / \mathrm{Ca}_{10}\left(\mathrm{PO}_{4}\right)_{6} \mathrm{~F}_{2}, \quad \times 32000$.

the minerals [20]. For this purpose there was used the method of high-temperature microscopy, as well differential thermal and $\mathrm{X}$-ray phase analyses.

Projecting of the inorganic filler compositions was realized by means of simplexlattice planning (the Sheffe method).

The composite materials were prepared by standard laboratory methods. The ingredients were mixed under normal conditions during 50-60 sec to obtain a homogeneous material without structure inhomogeneities. According to the existing practice, the materials were produced in real-life surgeries; then the mixture was placed into a mold and subjected to the reaction of structuring during $30 \mathrm{~min}$. The strength properties of the material (breaking bending and compression stress), as well as its adhesion and deformation (deflection angle) characteristics were determined by standard laboratory methods using a multipurpose tearing machine of "Dynstant" type .

\section{Results \& discussion}

The performed study shows that the optimum ratio for the components of the solidphase synthesis of $\mathrm{Ca}_{10}\left(\mathrm{PO}_{4}\right)_{6} \mathrm{~F}_{2}$ is to be determined taking into account volatility of the phosphorus compounds used in the capacity of precursors. This is due to the fact that the said property gives rise to certain complications in the process of solid-phase synthesis of calcium phosphates [21]. The established optimum ratio of the components is presented in Table 1 . The results of $\mathrm{X}$-ray phase analysis testify that the products of $\mathrm{Ca}_{3}\left(\mathrm{PO}_{4}\right)_{2}$ and $\mathrm{Ca}_{10}\left(\mathrm{PO}_{4}\right)_{6} \mathrm{~F}_{2}$ synthesis are high-purity nanocrystalline materials. Fig. 1 presents electron microscopic photographs of the microstructure of nanocrystalline $\mathrm{Ca}_{3}\left(\mathrm{PO}_{4}\right)_{2} \quad$ (a) and $\mathrm{Ca}_{3}\left(\mathrm{PO}_{4}\right)_{2} / \mathrm{Ca}_{10}\left(\mathrm{PO}_{4}\right)_{6} \mathrm{~F}_{2}(\mathrm{~b})$ powders.

Earlier investigations of the transformations of one polymorphic modification of $\mathrm{Ca}_{3}\left(\mathrm{PO}_{4}\right)_{2}$ into another modification [22, 23] confirmed the presence of two structure transitions: $\beta-\mathrm{Ca}_{3}\left(\mathrm{PO}_{4}\right)_{2} \rightarrow \alpha-\mathrm{Ca}_{3}\left(\mathrm{PO}_{4}\right)_{2}$ and $\alpha-\mathrm{Ca}_{3}\left(\mathrm{PO}_{4}\right)_{2} \rightarrow \alpha^{\prime} \mathrm{Ca}_{3}\left(\mathrm{PO}_{4}\right)_{2}$. As found in the present study, the transformation $\beta-\mathrm{Ca}_{3}\left(\mathrm{PO}_{4}\right)_{2} \rightarrow \alpha-\mathrm{Ca}_{3}\left(\mathrm{PO}_{4}\right)_{2}$ is not as fast as the one reported in [23]. This transition is slow. The DTA curves show the effect in $1180-1200^{\circ} \mathrm{C}$ temperature interval. However, final formation of $\alpha-\mathrm{Ca}_{3}\left(\mathrm{PO}_{4}\right)_{2}$ structure takes place at considerably higher temperatures, and is completed only at $1380-1400^{\circ} \mathrm{C}$. The transformation $\alpha-\mathrm{Ca}_{3}\left(\mathrm{PO}_{4}\right)_{2} \rightarrow \alpha^{\prime}-\mathrm{Ca}_{3}\left(\mathrm{PO}_{4}\right)_{2}$ is fast and occurs at a temperature of $\sim 1430^{\circ} \mathrm{C}$. This permits to obtain $\mathrm{Ca}_{3}\left(\mathrm{PO}_{4}\right)_{2}$ nanoparticles of a fragmentary structure which simultaneously contains two different phases: $\alpha$ - and $\beta$-modifications of $\mathrm{Ca}_{3}\left(\mathrm{PO}_{4}\right)_{2}$ separated by a coherent boundary. $\mathrm{ZrO}_{2}$ nanoparticles with similar properties investigated by Academician V.A.Shevchenko were called "centaurs" [18]. $\quad \mathrm{Ca}_{3}\left(\mathrm{PO}_{4}\right)_{2}$ nanoparticles are the crystals which interior is composed of non-hydrated $\beta$-modification of $\mathrm{Ca}_{3}\left(\mathrm{PO}_{4}\right)_{2}$, whereas the outer part is its hydrated $\alpha$-form.

The high-temperature $\alpha-\mathrm{Ca}_{3}\left(\mathrm{PO}_{4}\right)_{2}$ modification differs from the $\beta$-modification by the fact that it is of apatite nature. Therefore, its formula should be written as $\mathrm{Ca}_{9} \square\left(\mathrm{PO}_{4}\right)_{6} \square_{2}$, where $\square$ is vacancy.

When the organic and inorganic components are being mixed in the process of preparation of the composite material, there 


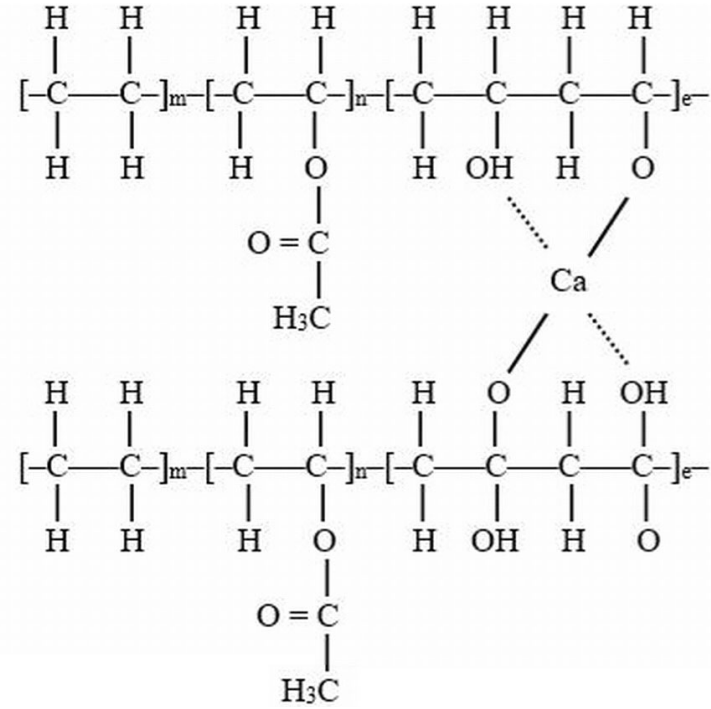

Fig. 2. Intermolecular structuring of the hybrid organo-inorganic composite material of incorporative type due to the formation of chelate complexes resulting in essential rise of the resistance of the composite to the action of biological medium of the organism.

occurs partial hydrolysis of $\mathrm{Ca}_{9} \square\left(\mathrm{PO}_{4}\right)_{6} \square_{2}$ in aqueous medium. Thereat, the substance transforms into a crystalline hydroxyl apatite of non-stoichiometric composition with channels half-filled with water:

$$
\begin{gathered}
\mathrm{Ca}_{9} \square\left(\mathrm{PO}_{4}\right)_{6} \square_{2}+\mathrm{H}_{2} \mathrm{O} \rightarrow \\
\rightarrow \mathrm{Ca}_{9} \square\left(\mathrm{PO}_{4}\right)_{5}\left(\mathrm{HPO}_{4}\right)(\mathrm{OH}) \square .
\end{gathered}
$$

Hereinafter, being durably incorporated into the physiological medium which contains, besides $\mathrm{OH}^{-}, \mathrm{Ca}^{2+}$ ions, nonstoichiometric hydroxyl apatite $\mathrm{Ca}_{9} \square\left(\mathrm{PO}_{4}\right)_{5}\left(\mathrm{HPO}_{4}\right)(\mathrm{OH})$ absorbs them and transforms into crystalline hydroxyl apatite of stoichiometric composition:

$$
\begin{aligned}
& \mathrm{Ca}_{9} \square\left(\mathrm{PO}_{4}\right)_{5}\left(\mathrm{HPO}_{4}\right)(\mathrm{OH}) \square+\mathrm{Ca}^{2+}+\mathrm{OH}^{-} \rightarrow(2) \\
& \rightarrow \mathrm{Ca}_{10}\left(\mathrm{PO}_{4}\right)_{6}(\mathrm{OH})_{2} .
\end{aligned}
$$

Thus, the formation of hydroxyl apatite from $\mathrm{Ca}_{3}\left(\mathrm{PO}_{4}\right)_{2}$ is presented by the scheme:

$$
\begin{gathered}
\mathrm{Ca}_{9} \square\left(\mathrm{PO}_{4}\right)_{6} \square_{2}+\mathrm{H}_{2} \mathrm{O} \rightarrow \\
\rightarrow \mathrm{Ca}_{9} \square\left(\mathrm{PO}_{4}\right)_{5}\left(\mathrm{HPO}_{4}\right)(\mathrm{OH}) \square+\mathrm{Ca}^{2+}+\mathrm{OH}^{-} \rightarrow \\
\rightarrow \mathrm{Ca}_{10}\left(\mathrm{PO}_{4}\right)_{6}(\mathrm{OH})_{2}
\end{gathered}
$$

or

$$
\begin{gathered}
\mathrm{Ca}_{9} \square\left(\mathrm{PO}_{4}\right)_{6} \square_{2}+\mathrm{Ca}(\mathrm{OH})_{2} \rightarrow \\
\rightarrow \mathrm{Ca}_{10}\left(\mathrm{PO}_{4}\right)_{6}(\mathrm{OH})_{2} .
\end{gathered}
$$

At intraosseous use (in the capacity of inorganic filler for a composite material of incorporative type), a fragmentary structure of an inorganic filler is being formed in a humid medium of a living organism. Thereat, in the process of hydration there appear the outer hydroxyl apatite layer of the stoichiometric composition and the interior layer of the non-stoichiometric composition. Introduction of such an inorganic filler into aqueous solution of the polymer material makes it possible to obtain a frame of three-dimensional structure with high mechanical strength due to formation of hydroxyl apatite of the non-stoichiometric $\mathrm{Ca}_{9} \square\left(\mathrm{PO}_{4}\right)_{5}\left(\mathrm{HPO}_{4}\right) \mathrm{OH} \square$, and then of the stoichiometric structure. Thus, the synthesis of calcium phosphate materials by the method of solid-phase sintering at temperatures of $1000-1300^{\circ} \mathrm{C}$ with subsequent treatment by the ceramic technology allowed to obtain nanocrystalline powders with controlled micro- and macro-structure (porosity).

Introduction of the filler based on calcium phosphate favors partial stitching of the spirit fragments of the ternary copolymer followed by formation of intermolecular chelate compound. As a result, rigidity of the composite and its resistance to the action of aqueous media, including biological ones, essentially rises. Shown in Fig. 2 is the scheme of intermolecular structuring of the hybrid organo-inorganic composite material of incorporative type due to the formation of chelate complexes. The processes which take place during the obtaining of such materials have a physico-chemical character. Their heating power is insignificant in comparison with that of the exothermal processes which occur at structuring of well-known bone cements. Therefore, the temperature in the "composite material bone tissue" contact zone must not be higher than $20-22^{\circ} \mathrm{C}$.

Thus, during the formation and subsequent exploitation of the hybrid organoinorganic composite with sevilen based binder and the inorganic filler based on finely dispersed calcium phosphate, there are observed several processes which take place simultaneously at different rates. Such processes lead to stabilization of the strength properties of the material and include partial hydration of the filler, intermolecular structuring due to formation of chelate complexes, as well as partial hydrolysis of sevilen followed by the formation of the ternary ethylene-vinylacetate- 


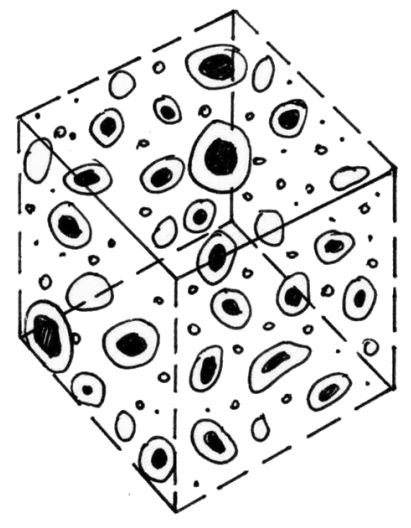

Inorganic nanocrystalline filler

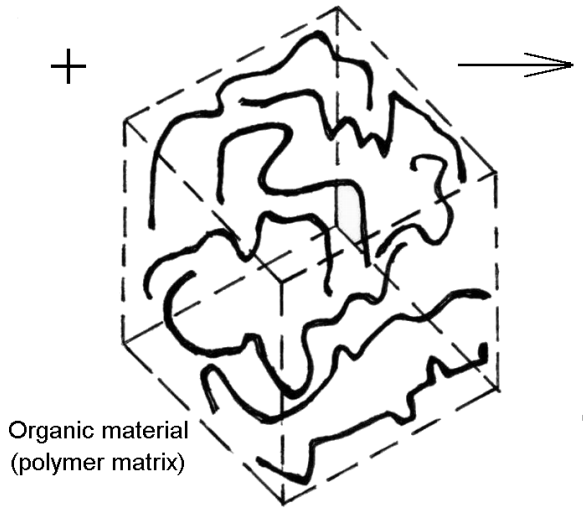

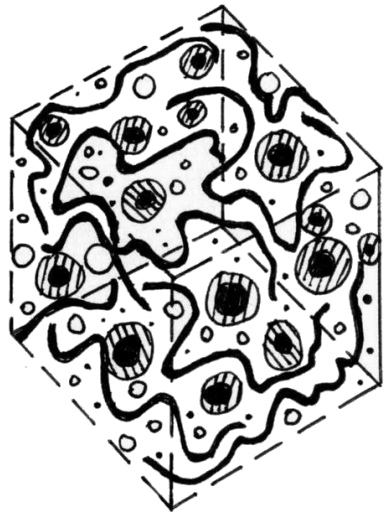

Organo-inorganic nanocomposite material of incorporative type

Fig. 3. Schematic structure of the organo-inorganic hybrid nanocomposite material of incorporative type.

Table 2. Physico-mechanical properties of hybrid organo-inorganic composite material based on sevilen and polyvinyl alcohol with nanodisperse calcium phosphate filler

\begin{tabular}{|c|c|c|c|c|c|}
\hline \multirow{2}{*}{$\begin{array}{l}\text { No. of } \\
\text { composition } \\
\text { according to } \\
\text { Table } 1\end{array}$} & \multicolumn{5}{|c|}{ Parameter } \\
\hline & $\begin{array}{c}\text { Adhesive } \\
\text { strength at } \\
\text { steady shear, } \\
\mathrm{MPa}\end{array}$ & $\begin{array}{c}\text { Temperature at } \\
\text { "bone tissue - } \\
\text { composite" } \\
\text { boundary, }{ }^{\circ} \mathrm{C}\end{array}$ & $\begin{array}{c}\text { Breaking } \\
\text { compressive stress, } \\
\mathrm{MPa}\end{array}$ & $\begin{array}{c}\text { Breaking } \\
\text { bending stress, } \\
\mathrm{MPa}\end{array}$ & $\begin{array}{l}\text { Deflection } \\
\text { angle, deg }\end{array}$ \\
\hline 1 & 7.2 & 20 & 70 & 45 & 9.0 \\
\hline 2 & 7.8 & 20 & 72 & 50 & 8.0 \\
\hline 3 & 9.3 & 20 & 73 & 38 & 9.0 \\
\hline 4 & 6.5 & 20 & 75 & 42 & 9.0 \\
\hline 5 & 6.8 & 20 & 70 & 35 & 9.0 \\
\hline 6 & 6.3 & 20 & 72 & 30 & 10.0 \\
\hline 7 & 6.5 & 20 & 70 & 38 & 8.0 \\
\hline 8 & 6.0 & 20 & 70 & 35 & 7.8 \\
\hline 9 & 6.0 & 20 & 75 & 34 & 9.0 \\
\hline 10 & 5.8 & 20 & 70 & 37 & 9.0 \\
\hline 11 & 6.3 & 20 & 71 & 33 & 10.0 \\
\hline 12 & 5.0 & 20 & 68 & 40 & 8.0 \\
\hline 13 & 5.4 & 20 & 70 & 35 & 7.9 \\
\hline 14 & 5.4 & 20 & 65 & 35 & 8.2 \\
\hline 15 & 5.8 & 20 & 70 & 40 & 8.5 \\
\hline 16 & 5.5 & 20 & 68 & 42 & 8.7 \\
\hline 17 & 6.0 & 20 & 73 & 39 & 8.0 \\
\hline 18 & 6.3 & 20 & 71 & 37 & 8.1 \\
\hline
\end{tabular}

The following examples characterize the influence of certain factors on the physico-mechanical properties of the hybrid organo-inorganic composite material: 6, 7: the molecular mass of ethylene-vinyl acetate copolymer; 8, 9: the content of vinyl acetate in the composition material; 10, 11: the content of acetate groups in polyvinyl alcohol; 12, 13: $\mathrm{Ca}_{3}\left(\mathrm{PO}_{4}\right)_{2}$ to fluorine apatite ratio in the inorganic filler; 14: the content of vinyl acetate in the composite material; $15:$ the content of acetate groups in polyvinyl alcohol; $12,16: \mathrm{Ca}_{3}\left(\mathrm{PO}_{4}\right)_{2}$ to fluorine apatite ratio in the inorganic filler; 17, 18: the content of vinyl acetate in the composite material. 
vinyl alcohol copolymer. The rate and completeness of each of these processes depend on the ratio of ingredients in the composite material, the structure of the filler, the properties of the binder, the temperature and other factors. However, as a rule, complete stabilization of the strength and working characteristics occurs only since 1520 days. The scheme of the organo-inorganic composite material of incorporative type is shown in Fig. 3.

There was studied the influence of the composition, macrostructure, thermal treatment conditions for the powders, on the physico-mechanical and biomedical properties of the obtained hybrid organo-inorganic composites. The composition and the physico-mechanical properties of the material are presented in Tables 1 and 2, respectively. As seen from Table 2, the maximum adhesive strength with respect to bone tissue at steady shear and high level of the strength properties is characteristic of the material of composition No. 2. The optimum content of $\mathrm{Ca}_{10}\left(\mathrm{PO}_{4}\right)_{6} \mathrm{~F}_{2}$ in the inorganic filler is determined, and it is shown that its introduction raises the strength and stability of the composite in the medium of a living organism. In this connection the material is obviously be effective for glueing together bone fragments. There has been estimated the influence of the ratio of ingredients and their composition on the behavior of the material in vivo (in warm-blooded animal organism at intraosteal application). The investigated materials have been found to be promising for filling cavities in bone tissue. The microstructure of the organo-inorganic composite material based on $\mathrm{Ca}_{3}\left(\mathrm{PO}_{4}\right)_{2}$ and sevilen after 28-day testing in vivo is presented in Fig. 4. As is seen, damage in the microstructure is absent.

\section{Conclusions}

Developed is the concept for the obtaining of the hybrid organo-inorganic composite material of incorporative type based on the use of $\mathrm{Ca}_{3}\left(\mathrm{PO}_{4}\right)_{2}$ nanoparticles in the capacity of inorganic filler, which structure simultaneously contains two different phases: $\alpha$ - and $\beta$-modifications of $\mathrm{Ca}_{3}\left(\mathrm{PO}_{4}\right)_{2}$ separated by a coherent boundary.

There is established the possibility to synthesize $\mathrm{Ca}_{3}\left(\mathrm{PO}_{4}\right)_{2}$ nanocrystals which interior is composed of non-hydrated $\beta$-modification of $\mathrm{Ca}_{3}\left(\mathrm{PO}_{4}\right)_{2}$, whereas the outer part is its hydrated $\alpha$-form. Thereat, both parts are separated by a coherent boundary. It is shown that the introduction of this

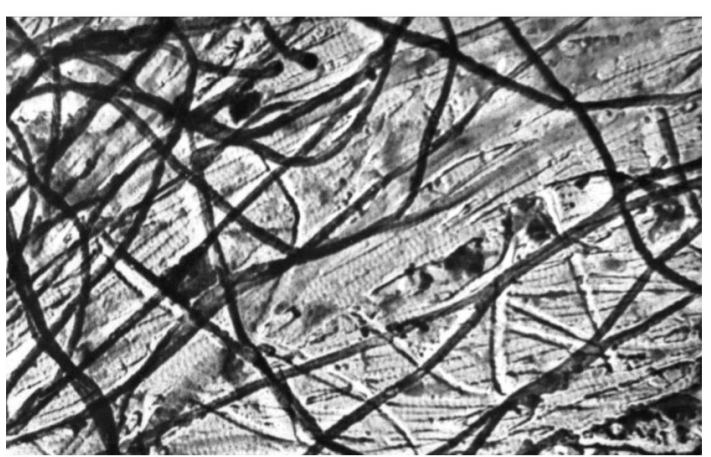

Fig. 4. Microstructure of the organo-inorganic composite material of incorporative type based on $\mathrm{Ca}_{3}\left(\mathrm{PO}_{4}\right)_{2}$ and sevilen since 28 days of testing in vivo, $\times 70000$.

inorganic filler into aqueous solution of the polymer material allows to obtain a strong frame of three-dimensional structure with high mechanical strength due to formation of hydroxyl apatite of the non-stoichiometric and then of the stoichiometric structure.

Developed is a simplified technological scheme for the synthesis of bioceramic materials to be used in the capacity of fillers for organo-inorganic biocomposites of incorporative type.

There is studied the influence of the ratio of ingredients in the composite material, the structure of the filler, the properties of the binder and the temperature, on the rate of the processes leading to stabilization of the strength properties of the composite and the degree of their completeness.

The processes which occur during the formation and exploitation of the polymer composite in vivo, are investigated.

The performed study is a basis for the creation of technological foundations for the obtaining of a new generation of functional materials for biomedical purposes, namely, hybrid organo-inorganic composites of incorporative type possessing a specific three-dimensional structure and predetermined properties.

\section{References}

1. L.L.Hench, Science, 295, 5 (2002).

2. D.Logeart-Avramoglou, F.Anagnoston, R.Bizios, H.Petite, J.Cell. Mol. Med., 9, 1 (2005).

3. O.Sych, N.Pinchuk, A.Parkhomey et al., Functional Materials, 14, 4 (2007).

4. V.Scorokhod, L.Ivanchenko, N.Pinchuk et al., Functional Materials, 13, 260 (2006).

5. O.Otychenko, T.Babutina, O.Kuda et al., Functional Materials, 24, 4 (2017). 
6. S.M.Barinov, V.S.Komlev, Calcium Phosphate Based Bioceramics, Nauka Publ., Moscow (2005) [in Russian].

7. V.V.Smirnov, S.M.Barinov, V.S.Komlev, M.A.Goldberg, Mater. Scie., 6 (2012).

8. K.T.Chu, Y.Oshida, E.B.Hancock et al., Biomed. Mater. Eng., 14, 87 (2004).

9. S.B.Kim, Y.J.Kim, S.A.Park et al., Biomater., 25, 5715 (2004).

10. J.Donaldson, H.E.Thomson, N.J.N.J.Harper, N.W.Kenny, British J.Anaesthesia, 102, 1 (2009).

11. R.Raisin, O.Effat, M.N.Shahidan et al., $J$. Pathalogy, 35, 1 (2009).

12. T.L.Norman, T.Shultz, G.Noble et al., $J$. Biomechanics. 46, 5 (2013).

13. G.Gould, T.Goswami, Int.J.Biomed.Eng. Techn., 11, 2 (2013).

14. Y.Chang, C.L.Tai, P.H.Hsieh, S.W.Ueng, Bone Joint Res.. 15, 2 (2013).
15. S.Zhilong, K.G.Neoh, E.T.Kang, Biomater., 27, 11 (2006).

16. R.K.Roeder, G.L.Converse, R.J.Kane, W.Yee, Biolog. Mater. Science, 3, 139 (2008).

17. S.Krivileva, A.Rassokha, Minerals and Mountain Breeds, Point Publ., Kharkiv (2014) [in Russian].

18. V.Shevchenko, M.Balmakov, Phys.Chem. Glass, 28, 6 (2002).

19. A.Rassokha, S.Krivileva, Bulletin of NTU "KhPI", 57, 1030 (2013).

20. A.N.Vinchell, G.Vinchell. Optical Properties of Artificial Minerals, Moscow (1980) [in Russian].

21. D.Corbrigj, Phosphorus: the Fundamentals of Chemistry, Biochemistry, Technology, Wold Publ., Moscow (1980) [in Russian].

22. S.Krivileva, V.Moiseev, Functional Materials, 25, 358 (2018).

23. P.Huron, In-NoJung. Metallurg. Mater. Trans. $B, 1,46$ (2015). 